\title{
A case series of third-trimester raltegravir initiation: Impact on maternal HIV-1 viral load and obstetrical outcomes
}

\author{
I Boucoiran MD MSc ${ }^{1,2}$, K Tulloch PharmD ${ }^{1}, \mathrm{~N}$ Pick MD³, F Kakkar MD MPH ${ }^{4,5}$, J van Schalkwyk MD ${ }^{1,2}$, \\ D Money $\mathrm{MD}^{1,2}, \mathrm{M}$ Boucher $\mathrm{MD}^{5,6}$
}

\begin{abstract}
I Boucoiran, K Tulloch, N Pick, F Kakkar, J van Schalkwyk, D Money, M Boucher. A case series of third-trimester raltegravir initiation: Impact on maternal HIV-1 viral load and obstetrical outcomes. Can J Infect Dis Med Microbiol 2015;26(3):145-150.
\end{abstract}

OBJECTIVE: To describe the impact of initiating raltegravir (RAL)containing combination antiretroviral therapy (cART) regimens on HIV viral load (VL) in pregnant women who have high or suboptimal VL suppression late in pregnancy.

METHODS: HIV-infected pregnant women who started RALcontaining cART after 28 weeks' gestation from 2007 to 2013 were identified in two university hospital centres.

RESULTS AND DISCUSSION: Eleven HIV-infected women started RAL at a median gestational age of 35.7 weeks (range 31.1 to 38.0 weeks). Indications for RAL initiation were late presentation in pregnancy $(n=4)$ and suboptimal VL suppression secondary to poor adherence or viral resistance $(n=7)$. Mean $V L$ at the time of RAL initiation was 73,959 copies $/ \mathrm{mL}$ (range $<40$ to 523,975 copies $/ \mathrm{mL}$ ). Patients received RAL for a median of 20 days (range one to 71 days). The mean decline in VL from the time of RAL initiation to delivery was $1.93 \mathrm{log}$, excluding one patient who received only one RAL dose and one patient with undetectable VL at the time of RAL initiation. After eight days on RAL, $50 \%$ of the women achieved a VL $<1000$ copies $/ \mathrm{mL}$ (the threshold for recommended Caesarean section to reduce the risk for perinatal transmission). There were no cases of perinatal HIV transmission.

CONCLUSION: The present study provides preliminary data to support the use of RAL-containing cART to expedite HIV-1 VL reduction in women who have a high VL or suboptimal VL suppression late in pregnancy, and to decrease the risk of HIV perinatal transmission while avoiding Caesarean section. Further assessment of RAL safety during pregnancy is warranted.

Key Words: HIV-1; Integrase inhibitor; Pregnancy; Raltegravir; Viral load

$\mathrm{T}$ he availability of combination antiretroviral therapy (cART) has drastically reduced the risk of HIV-1 perinatal transmission. With cART, undetectable viral loads (VL) are achievable, allowing for vaginal delivery and perinatal transmission rates of $<1 \%$ to $2 \%$ in nonbreastfeeding women $(1,2)$. Before the use of antiretrovirals, the rate of HIV-1 perinatal transmission was $25 \%$ to $35 \%$ in North America, with
Une série de cas sur l'initiation du raltégravir au troisième trimestre : les répercussions de la charge virale du VIH-1 et les résultats obstétricaux

OBJECTIF : Décrire les répercussions de l'amorce d'une antirétrovirothérapie prophylactique associative (ARPA) contenant du raltégravir (RAL) sur la charge virale (CV) du VIH chez les femmes enceintes dont la suppression de la CV est élevée ou sous-optimale en fin de grossesse. MÉTHODOLOGIE : Les chercheurs ont extrait le dossier des femmes enceintes infectées par le VIH qui avaient amorcé une ARAP contenant du RAL après 28 semaines de grossesse dans deux centres hospitaliers universitaires entre 2007 et 2013.

RÉSULTATS ET EXPOSÉ : Onze femmes infectées ont entrepris un traitement de RAL à une médiane de 35,7 semaines de grossesse (plage de 31,1 à 38,0 semaines). Les indications pour entreprendre le RAL étaient une présentation tardive au suivi de grossesse $(n=4)$ et une suppression sous-optimale de la $\mathrm{CV}$ en raison d'un mauvais respect du traitement ou d'une résistance virale $(\mathrm{n}=7)$. La CV moyenne au début du traitement au RAL était de 73959 copies/mL (plage de moins de 40 copies/mL à 523975 copies/mL). Les patientes ont pris du RAL pendant une médiane de 20 jours (plage de un à 71 jours). La diminution moyenne de la CV entre le début du RAL et l'accouchement était de $1,93 \log$, à l'exception d'une patiente qui n'a reçu qu'une dose de RAL et d'une patiente dont la CV n'était pas décelable au moment d'entreprendre le RAL. Au bout de huit jours de RAL, $50 \%$ des femmes présentaient une CV inférieure à 1000 copies/mL (le seuil pour recommander une césarienne afin de réduire le risque de transmission périnatale). Il n'y a d'ailleurs eu aucun cas de transmission périnatale du VIH. CONCLUSION : La présente étude fournit des données provisoires pour soutenir l'utilisation d'ARPA contenant du RAL afin d'accélérer la réduction de la $\mathrm{CV}$ du VIH-1 chez les femmes qui présentaient une CV élevée ou une suppression sous-optimale de leur CV pendant la grossesse, ainsi que pour réduire le risque de transmission périnatale du VIH tout en évitant une césarienne. Une évaluation plus approfondie de l'innocuité du RAL est justifiée pendant la grossesse.

more than one-half of the cases occurring during the late antenatal period and delivery (3). The risk of perinatal transmission is proportional to maternal plasma VL at delivery (4). Therefore, reaching maximal viral suppression before delivery is the main goal of antiretroviral treatment in pregnancy. To further reduce the risk of transmission, North American guidelines recommend elective Caesarean

${ }^{1}$ Department of Obstetrics and Gynecology, University of British Columbia, BC Women's Hospital; 'Women's Health Research Institute,

BC Women's Hospital; ${ }^{3}$ Division of Infectious Diseases, University of British Columbia, BC Women's Hospital, Vancouver, British Columbia;

${ }^{4}$ Division of Infectious Diseases, Centre hospitalier universitaire Sainte-Justine and Department of Pediatrics, Faculty of Medicine, Universite de

Montréal; ${ }^{5}$ Centre Maternel et Infantile sur le SIDA, Centre hospitalier universitaire Sainte-Justine; ${ }^{6}$ Department of Obstetrics and

Gynecology, Université de Montréal, Centre hospitalier universitaire Sainte-Justine, Montreal, Quebec

Correspondence: Dr I Boucoiran, BC Women's Hospital and Health Centre, B327-4500 Oak Street, Box 42, Vancouver,

British Columbia V6H 3N1. Telephone 604-875-2424 ext 4874, fax 604-875-3895, e-mail isabelle@boucoiran.fr 
delivery at 38 weeks' gestation for women when the last measured VL is $>1000$ copies $/ \mathrm{mL}(4,5)$.

Late presentation of pregnant women with HIV, either due to limited or absent prenatal care or acquisition of HIV in late pregnancy, continues to occur and hinders the timely initiation of HIV perinatal transmission preventive measures (6). An Italian cohort study reported that $16 \%$ of new HIV-infection diagnoses during pregnancy occurred in the third trimester (7), and $20 \%$ of HIV-infected pregnant women presented beyond 28 weeks of pregnancy at the major HIV reference centre in Bahia, Brazil (8). Canadian data reported by the Perinatal HIV Surveillance Program found that between 1997 and 2011, 13\% of the HIV-infected pregnant women received no antiretroviral therapy and $17 \%$ received $<4$ weeks of antiretrovirals (9). In 2011 in Canada, 10\% of HIV-infected pregnant women had received none or $<4$ weeks of antiretrovirals. Because women continue to present in late pregnancy with suboptimal VL suppression despite the availability of cART, new therapeutic modalities are required to achieve a prompt decline of HIV VL to decrease the risk of perinatal transmission, potentially also obviating the need for an HIV-indicated Caesarean section.

Raltegravir (RAL) is an HIV-1 integrase strand transfer inhibitor that leads to potent viral suppression while maintaining a favourable adverse effect profile and minimal drug interactions (10). Its effectiveness to rapidly control HIV VL has been demonstrated in patients with drug resistance as well as in the antiretroviral-naive population (11-14). Although there are limited data regarding the use of RAL in pregnancy, there is increasing anecdotal evidence of its efficacy to rapidly reduce maternal VL when used as a part of cART regimens late in pregnancy, with few maternal side effects and no detrimental effects on the fetus $(8,15-26)$.

The objective of our case series was to describe the impact of initiating RAL-containing cART regimens on HIV VL in pregnant women who have high or suboptimal VL suppression late in pregnancy.

\section{METHODS}

A retrospective review of two Canadian HIV perinatal databases (those of the Oak Tree Clinic at BC Woman's Hospital, Vancouver, British Columbia, and of the Grossesse Avec Maladie Infectieuse clinic at SainteJustine Hospital, Montreal, Quebec) was conducted to identify HIVinfected pregnant women who initiated treatment with RAL (400 mg twice per day orally) after 28 weeks' gestation. Data collected between 2007, the year when RAL became available, and December 2013 were reviewed. Each patient's chart was then retrospectively abstracted for data including RAL indication, tolerance and timing of exposure.

The standard of care in both clinics included treatment of HIV. infected pregnant women with cART regardless of baseline CD4 cellcount and HIV-1 VL, as well as assessment of the women's clinical, virological and immunological status every four weeks. Toxicity due to the antiretrovirals was monitored at these times. Infants were evaluated at least at birth, two weeks of age, one month of age and then every three to four months until 18 months of age. HIV-negative status in infants was defined presumptively by at least two negative HIV RNA polymerase chain reaction test results before four months of age, and confirmed by the absence of HIV-1 antibody at 18 months of age.

Maternal and neonatal adverse reactions were systematically addressed according to WHO criteria (27), with specific attention devoted to hematological and hepatic complications.

HIV-1 VL was measured either using the Ultrasensitive Amplicor HIV-1 Monitor Test or COBAS TaqMan HIV-1 Test, v1.0 (Roche Molecular Systems Inc, USA) for cases in Vancouver, and the Abott RealTime HIV-1 assay (Abbott Molecular Inc, USA) for cases in Montreal.

The study was approved by the institutional review board of each centre.

\section{Statistics}

A descriptive analysis of population characteristics was performed. Because of the non-normal distribution, median and range are reported.
A nonparametric survival analysis was then conducted to compute the time to achieve a $\mathrm{VL}<50$ copies $/ \mathrm{mL}$ and $<1000$ copies $/ \mathrm{mL}$, respectively. The statistical analysis was performed using $\mathrm{R}$ version 2.11 .1 (R Core Team, 2013).

\section{RESULTS}

A total of 11 women who initiated RAL during the third trimester of their pregnancies were identified. Their clinical and laboratory characteristics are summarized in Table 1 . The median age was 31 years (range 21 to 39 years). Five were antiretroviral-naive before pregnancy. Three women (cases 3, 5 and 7) had a new diagnosis of HIV during the current pregnancy. The median gestational age at their first clinic visit was 24 weeks (range seven to 35 weeks). The median duration of consistent cART received was 42 days (range seven to 202 days). No women had any previous exposure to RAL. Indications for RAL were late presentation in pregnancy $(n=4)$ and suboptimal VL reduction secondary to poor adherence or viral resistance $(n=7)$. All patients received RAL in combination with at least two other active antiretroviral agents, started at a median gestational age of 35.7 weeks (range 31.1 to 38.0 weeks). Exposure duration was a median of 20 days (range one to 71 days). Five women received $<2$ weeks of RAL.

The median gestational age at delivery was 38.7 weeks; one patient (case 9) delivered at 35 weeks in a context of spontaneous preterm labor. At the time of delivery, nine women had a HIV VL $<1000$ copies/mL, of which seven were $<50$ copies $/ \mathrm{mL}$. Figure 1 summarizes the typical VL evolution after RAL initiation.

Among the 11 women, three had a vaginal delivery, three had a Caesarean section for obstetrical indications and five had a Caesarean section to further decrease the risk of HIV perinatal transmission. Three of these Caesarean sections could have been avoided (ie, the VL was below threshold of 1000 copies/mL) if the HIV VL had been known at the time of the delivery.

Maternal RAL was discontinued after delivery in all 11 cases. There were no cases of HIV perinatal transmission observed in the in uteroexposed infants. One infant was believed to be breastfed (case 2). One infant (case 11) presented a transient symptomatic cardiac arrhythmia at birth, as well as unilateral hydronephrosis and skin abnormalities (nevus, four nipples), which were not prenatally diagnosed.

The following two cases were excluded from subsequent analysis:

- One woman (case 3) had an undetectable VL at RAL initiation. She was initially started with a combination regimen with zidovudine, lamivudine and ritonavir-boosted lopinavir at 28 weeks and four days. However, she had adherence issues in a context of a newly diagnosed HIV infection in pregnancy with hepatitis $\mathrm{C}$ coinfection and substance use. The woman was admitted for directly observed therapy and RAL was started at 33 weeks to rapidly suppress her VL. At the time of RAL initiation, the last available VL result (measured two weeks previously) was 1762 copies $/ \mathrm{mL}$, and the woman reported poor adherence to her cART regimen during this time period. Retrospectively, it was determined that at the time of RAL initiation, her VL was undetectable; however, because of concerns surrounding adherence and risk of resistance rise, RAL was pursued. The woman discharged herself from hospital for three days at approximately 35 weeks' gestation but returned with a positive urine cocaine screen. She had a vaginal delivery at 38 weeks and five days' gestation with a confirmed undetectable VL.

- One woman (case 10) received only one dose of RAL. Her pregnancy had been complicated by poor adherence and intolerance to cART. At 37 weeks' gestation, she was admitted for supervised cART, and her VL was found to be 232,245 copies $/ \mathrm{mL}$. As soon as this result was known, RAL was added to her regimen to attempt a rapid and maximal suppression of the HIV VL before delivery. However, $3 \mathrm{~h}$ after receiving the first dose of RAL the woman experienced spontaneous rupture of membranes and went into active labour.

In the remaining nine women, median VL at RAL initiation was 88,707 copies/mL (range 246 to 523,975 copies $/ \mathrm{mL}$; mean 73,959 copies $/ \mathrm{mL}$ ). The mean decline of $\mathrm{VL}$ from time of RAL 
TABLE 1

Summary of the 11 patients who initiated raltegravir during the third trimester for HIV perinatal transmission prophylaxis

\begin{tabular}{|c|c|c|c|c|c|c|c|c|c|c|c|c|c|c|c|}
\hline Case & $\begin{array}{l}\text { Age, } \\
\text { years }\end{array}$ & $\begin{array}{l}\text { ART } \\
\text { status }\end{array}$ & $\begin{array}{c}\text { Coinfec- } \\
\text { tion }\end{array}$ & $\begin{array}{l}\text { ART used } \\
\text { during } \\
\text { pregnancy } \\
\text { (in addition } \\
\text { to RAL) } \\
\end{array}$ & $\begin{array}{c}\text { Indications } \\
\text { for RAL } \\
\text { initiation }\end{array}$ & $\begin{array}{c}\text { GA at } \\
\text { RAL } \\
\text { initiation } \\
\text { (weeks) }\end{array}$ & $\begin{array}{c}\mathrm{CD} 4 \text { at } \\
\mathrm{RAL} \quad \mathrm{i} \\
\text { initiation } \\
\text { (cells } / \mathrm{mL} \text { ) }\end{array}$ & $\begin{array}{c}\mathrm{VL} \text { at } \\
\mathrm{RAL} \\
\text { initiation } \\
\text { (copies/ } \\
\mathrm{mL} \text { ) }\end{array}$ & $\begin{array}{l}\mathrm{VL} \text { at } \\
\text { delivery } \mathrm{E} \\
\text { (copies/ } \\
\mathrm{mL} \text { ) }\end{array}$ & $\begin{array}{l}\text { Exposure } \\
\text { to RAL } \\
\text { (days) }\end{array}$ & $\begin{array}{c}\mathrm{VL} \\
\text { decrease } \\
\left(\log _{10}\right. \\
\text { copies/ } \\
\mathrm{mL})\end{array}$ & Mode of delivery & $\begin{array}{c}\text { Peripartum } \\
\text { prophy- } \\
\text { laxis }\end{array}$ & $\begin{array}{l}\text { Infant I } \\
\text { prophy- } \\
\text { laxis s }\end{array}$ & $\begin{array}{c}\text { Infant } \\
\text { HIV } \\
\text { status } \\
\end{array}$ \\
\hline 1 & 31 & Exp & - & $\begin{array}{c}\mathrm{ABC}+3 \mathrm{TC} \\
+\mathrm{ATZ} / \mathrm{r}\end{array}$ & $\begin{array}{l}\text { VL rebound } \\
\text { despite dose } \\
\text { adjustment }\end{array}$ & 34.1 & 437 & 1562 & 40 & 43 & 1.59 & $\begin{array}{l}\text { Urgent C-section } \\
\text { for labour dystocia }\end{array}$ & AZT IV & $\begin{array}{l}\text { AZT } \\
+3 T C\end{array}$ & $\mathrm{Neg}$ \\
\hline 3 & 39 & Naive & $\mathrm{HCV}$ & $\begin{array}{l}\mathrm{AZT}+3 \mathrm{TCC} \\
+\mathrm{LPV} / \mathrm{r}\end{array}$ & $\begin{array}{l}\text { Late initiation } \\
\text { of ART, fear } \\
\text { of resistance } \\
\text { due to } \\
\text { compliance } \\
\text { issues }\end{array}$ & 33.4 & 308 & $<40$ & $<40$ & 34 & 0.00 & Vaginal delivery & AZT IV & $\begin{array}{l}\text { AZT } \\
+3 T C\end{array}$ & Neg \\
\hline 5 & 36 & Naive & - & $\begin{array}{l}\mathrm{AZT}+3 \mathrm{TC} \\
+\mathrm{LPV} / \mathrm{r}\end{array}$ & $\begin{array}{l}\text { VL rebound } \\
\text { despite } \\
\text { adequate } \\
\text { drug levels }\end{array}$ & 35.7 & 357 & 246 & $<40$ & 25 & 0.79 & $\begin{array}{l}\text { Emergent C-section } \\
\text { for nonreassuring } \\
\text { fetal heart rate and } \\
\text { choriamnionitis }\end{array}$ & AZT IV & $\begin{array}{l}\text { AZT } \\
+3 T C\end{array}$ & $\mathrm{Neg}^{*}$ \\
\hline 6 & 34 & Naive & - & $\begin{array}{l}\mathrm{AZT}+3 \mathrm{TC} \\
+\mathrm{LPV} / \mathrm{r}\end{array}$ & $\begin{array}{l}\text { Late } \\
\text { presentation }\end{array}$ & 36.3 & 132 & 523,975 & 1163 & 11 & 2.65 & $\begin{array}{l}\text { Elective C-section } \\
\text { for perinatal } \\
\text { transmission } \\
\text { prophylaxis }\end{array}$ & AZT IV & $\begin{array}{l}\text { AZT } \\
+3 T C \\
+N F V\end{array}$ & Neg \\
\hline 7 & 35 & Naive & - & $\begin{array}{c}\mathrm{AZT}+3 \mathrm{TC} \\
+\mathrm{LPV} / \mathrm{r}\end{array}$ & VL rebound & 37.6 & 484 & 695 & $<40$ & 13 & 1.24 & Vaginal delivery & AZT IV & $\begin{array}{l}\text { AZT } \\
+3 T C\end{array}$ & Neg \\
\hline 10 & 29 & Naive & $\mathrm{HCV}$ & $\begin{array}{c}\text { TDF+FTC } \\
+ \text { ATZ/r }\end{array}$ & $\begin{array}{l}\text { VL rebound } \\
\text { after } \\
\text { interruption } \\
\text { of ART }\end{array}$ & 38.0 & 50 & 15,153 & 15,153 & 1 & NA & $\begin{array}{l}\text { Elective C-section } \\
\text { for perinatal } \\
\text { transmission } \\
\text { prophylaxis }\end{array}$ & $\begin{array}{l}\text { AZT IV + } \\
\text { NVP po }\end{array}$ & $\begin{array}{l}\text { AZT } \\
+3 T C \\
+\mathrm{LPN} / \mathrm{r}\end{array}$ & Neg \\
\hline 11 & 22 & Naive & - & $\begin{array}{l}\text { TDF+FTC } \\
+ \text { ATZ/r then } \\
\text { ABC+3TC } \\
+ \text { ATZ/r }\end{array}$ & $\begin{array}{l}\text { VL rebound } \\
\text { after } \\
\text { interruption } \\
\text { of ART }\end{array}$ & 36.0 & 600 & 2287 & $<40$ & 35 & 1.76 & Vaginal delivery & AZT IV & AZT & Neg \\
\hline
\end{tabular}

${ }^{*}$ Confirmatory HIV serology at 18 months is pending. 3TC Lamivudine; ABC Abacavir; ATZ/r Atazanavir/ritonavir; ART Antiretroviral therapy; AZT Zidovudine; C-section Caesarean section; DRV/r Darunavir/ritonavir; Exp Experienced; FTC Emtricitabine; GA Gestational age; HCV Hepatitis C virus; IV Intravenous; LPV/r Lopinavir/ritonavir; NA Not applicable; Neg Negative; NFV Nelfinavir; NVP Nevirapine; RAL Raltegravir; TDF Tenofovir; VL HIV RNA viral load

initiation to delivery was $1.93 \log _{10}$ copies $/ \mathrm{mL}(95 \%$ CI 1.32 to $2.53 \log _{10}$ copies $/ \mathrm{mL}$ ) (Figure 1). In the four women who received $<2$ weeks of RAL, the mean VL decrease was $1.82 \log _{10}$ copies $/ \mathrm{mL}$. In the four women who had an initial VL $>4 \log _{10}$ copies $/ \mathrm{mL}$, the mean decrease was $2.65 \log _{10}$ copies/mL. After eight days on RAL, $50 \%$ of the women achieved a VL $<1000$ copies/mL (Figure 2). Similarly, 50\% of the women achieved a VL $<50$ copies $/ \mathrm{mL}$ after 26 days on $\mathrm{RAL}$.

Only one maternal adverse event was observed (case 6). An asymptomatic elevation of liver enzyme levels (11- and fivefold the upper limit of normal of alanine aminotransferase and aspartate aminotransferase, respectively) was noted in a woman for whom RAL was added to a combination of zidovudine, lamivudine and ritonavirboosted lopinavir because of late presentation. The elevation of liver enzyme levels was first observed after five days on RAL, without signs of preeclampsia or cholestasis. The status regarding hepatitis A, B and $\mathrm{C}$ infections was confirmed to be negative. After RAL discontinuation, liver enzyme levels immediately began to decrease significantly. This case has previously been described by the authors' team (23). 
TABLE 2

Summary of previous published case reports of raltegravir initiation during the third trimester of pregnancy

\begin{tabular}{|c|c|c|c|c|c|c|c|c|c|}
\hline $\begin{array}{l}\text { First author } \\
\text { (reference), year }\end{array}$ & $\begin{array}{l}\text { Number } \\
\text { of cases }\end{array}$ & $\begin{array}{c}\text { GA at RAL } \\
\text { initiation, } \\
\text { weeks, } \\
\text { range }\end{array}$ & $\begin{array}{l}\text { Exposure to } \\
\text { RAL, days, } \\
\text { range }\end{array}$ & $\begin{array}{l}\text { HIV RNA at RAL } \\
\text { initiation, } \\
\text { copies } / \mathrm{mL}, \\
\text { range }\end{array}$ & $\begin{array}{l}\text { HIV RNA at } \\
\text { delivery, } \\
\text { copies/mL, }\end{array}$ & $\begin{array}{l}\text { HIV RNA } \\
\text { decrease, } \\
\log _{10} \text { copies/ } \\
\text { mL, range }\end{array}$ & $\begin{array}{c}\text { Undetectable } \\
\text { viral load at } \\
\text { delivery, } \\
n\end{array}$ & Mode of delivery & $\begin{array}{c}\text { Perinatal } \\
\text { transmission, } \\
n\end{array}$ \\
\hline McKeown (16), 2010 & 3 & $28-39$ & $11-17$ & $183-67,100$ & $40-185$ & $0.66-2.56$ & 2 & C-section & 0 \\
\hline Taylor (18), 2010 & 5 & $33-34$ & $17-46$ & $51-48,884$ & $<40-380$ & $0.11-3.16$ & 3 & C-section & 0 \\
\hline Lopez-Valera (19), 2012 & 1 & 35 & 28 & 1902 & $<50$ & 1.58 & 1 & Vaginal delivery & 0 \\
\hline Hegazi (24), 2013 & 1 & 29 & 71 & $1,740,000,000$ & 208 & 6.92 & 0 & C-section & 0 \\
\hline Cha (25), 2013 & 1 & 33 & 35 & 106,110 & 200 & 2.72 & 0 & C-section & 0 \\
\hline De Hoffer (26), 2013 & 1 & 35 & 19 & 8903 & $<20$ & 2.65 & 1 & C-section & 0 \\
\hline
\end{tabular}

*Viral load the day of delivery or, if it was not reported, viral load the closest to the day of delivery. C-section Caesarean section; GA Gestational age; RAL Raltegravir

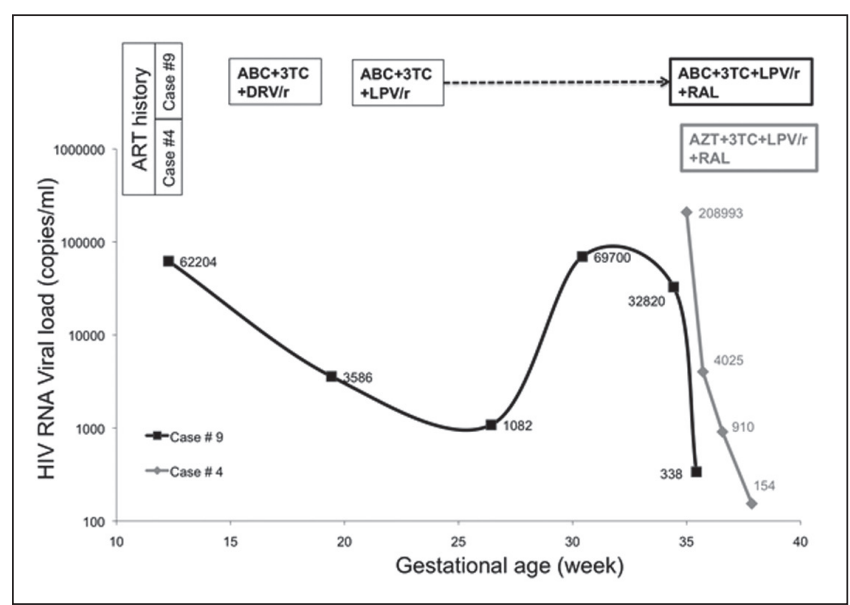

Figure 1) Examples of HIV RNA viral load evolution after raltegravir $(R A L)$ initiation late in pregnancy. Case 4: a 33-year-old woman from Haiti who had recently immigrated to Canada was first seen at the authors' clinic at 35 weeks' gestation. A combination of zidovudine (AZT), lamivudine (3TC), boosted lopinavir ( $L P V / r$ ) and RAL was immediately started. An elective Caesarean section was performed at 38 weeks, after intravenous zidovudine. At delivery, the HIV viral load was retrospectively found to be 154 copies/mL. Case 9: a 29-year-old First Nations nulliparous woman coinfected with hepatitis $\mathrm{C}$ with a history of substance abuse was first seen at 10 weeks' gestation. Because of tolerance and adherence issues, her viral load was 32,820 copies/mL at 34 weeks' gestation. She was admitted to hospital for supervised combination antiretroviral drug therapy (ART) containing RAL and received a total of seven days of this regimen. An emergent Caesarean section was performed at 35 weeks' gestation in the context of preterm labour, after an intravenous loading dose of AZT and a single-dose of oral nevirapine $200 \mathrm{mg}$. At delivery, her HIV viral load was retrospectively found to be 338 copies/mL. Both newborns were uninfected. ABC Abacavir

\section{DISCUSSION}

In our experience, adding RAL to a cART regimen was useful in rapidly reducing HIV-1 VL to prevent perinatal transmission in women who have high VL or suboptimal suppression late in pregnancy.

Our findings are consistent with previously published cases of RAL use late in pregnancy, which are summarized in Table 2 (8,15-18,20 22,24-26,28). Among these, only one case of perinatal transmission has been reported (8); the clinical presentation in that case suggested in utero HIV transmission. No neonatal safety issues have been observed among the published cases.

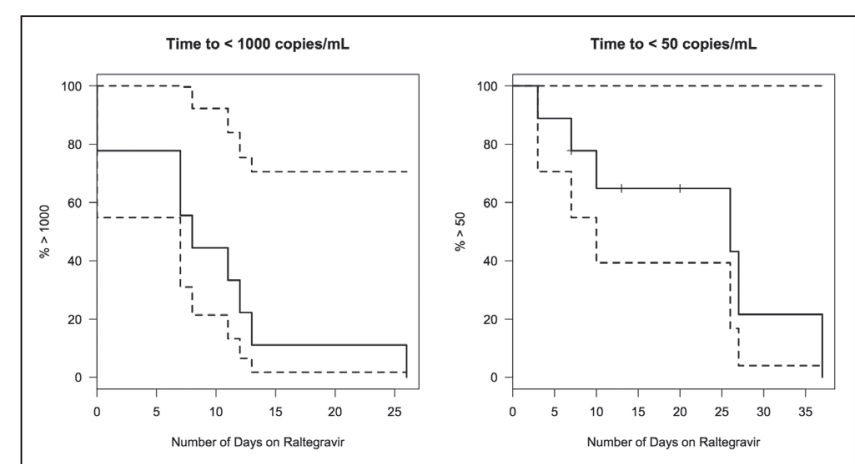

Figure 2) Time to achieve a HIV viral load $<1000$ copies $/ \mathrm{mL}$ and $<50$ copies/mL after raltegravir initiation during the third trimester $(n=10)$. Dotted lines represent CIs

We were able to confirm the drastic and rapid decrease of HIV VL after RAL initiation, and computed a median time to achieve $\mathrm{VL}<1000$ copies/mL (eight days), information that will be useful in the clinical setting. However, the low number of subjects limits the generalizability of our findings. Moreover, important limitations of the present case series include the absence of data regarding resistance to integrase inhibitors among the women treated, and regarding maternal and neonatal RAL plasma concentrations. Published data indicate that, despite a reduction of RAL median area under the curve by approximately $50 \%$ during pregnancy (29), RAL readily crosses the placenta and achieves adequate concentrations in the neonate, with mean cord blood-maternal blood drug ratios of 1.5 (range 0.32 to 9.5) $(15,16,22,28)$. Else et al (30) found that RAL achieves the highest placental/neonatal concentration among available antiretroviral medications. Explanations for effective placental transfer of RAL include its relatively low protein binding and small molecular weight, as well as its favourable $\mathrm{pH}$-dependent lipophilicity, which results in increased amount of ionized drug in the fetal circulation $(11,22,30,31)$. A high cord:maternal serum ratio reflects a high placental transfer but also a neonatal accumulation. The ability of fetuses to metabolize and eliminate RAL on their own is likely limited by the immaturity of UGTglucuronidation pathways $(22,32)$.

We observed a $1.82 \log _{10}$ copies/mL decrease in HIV VL within two weeks of receipt of a RAL-containing cART regimen, which is faster than the mean time of approximately five weeks to suppression that is typically observed with traditional cART (33). This finding is consistent with the VL reductions ( $2 \log _{10}$ copies $/ \mathrm{mL}$ within 10 to 14 days of receipt of a RAL-based regimen) observed in randomized controlled trials using RAL-based regimens (12-14) and 
in observational studies investigating RAL administration late in pregnancy $(8,15,16,18,21)$.

The reported case of liver toxicity (23) is, to our knowledge, the second that has been described with RAL use in pregnancy (29). Although hepatotoxicity is one of the well-recognized side effects of antiretroviral drugs, it has not been commonly associated with RAL therapy, with increase of aspartate aminotransferase and alanine aminotransferase levels $>5$ times the upper limit of normal seen in only $5 \%$ of exposed individuals $(31,34)$. Sufficient data are not yet available to conclude whether the risk of hepatotoxicity is higher in pregnancy. Close follow-up of liver enzyme levels in pregnant women treated with RAL would be prudent until more safety data are available.

RAL has not been associated with any congenital anomalies (31). The infant who was diagnosed with cardiac arrhythmia, unilateral hydronephrosis and skin anomalies had been exposed to RAL in utero for 35 days, starting at 36 weeks' gestation. Because of this timing, the congenital anomalies are not likely related to RAL exposure. However, safety data regarding RAL exposure in pregnancy are weak, and it remains a category $\mathrm{C}$ drug (31).

Considering the potential advantages of RAL noted above, it remains to be determined whether its ability to rapidly reduce VL in late pregnancy will reduce the need for Caesarean delivery and the rate of perinatal transmission for women who present near term with high VL. This would benefit HIV-infected women, particularly those with low CD4 cell counts, considering the increased risk of postpartum complications related to Caesarean delivery $(35,36)$. An important factor to consider, however, is the availability of rapid HIV quantitative test to

\section{REFERENCES}

1. Kourtis AP, Lee FK, Abrams EJ, Jamieson DJ, Bulterys M. Mother-to-child transmission of HIV-1: Timing and implications for prevention. Lancet Infect Dis 2006;6:726-32.

2. Forbes JC, Alimenti AM, Singer J, et al. A national review of vertical HIV transmission. AIDS 2012;26:757-63.

3. Connor EM, Sperling RS, Gelber R, et al. Reduction of maternalinfant transmission of human immunodeficiency virus type 1 with zidovudine treatment. Pediatric AIDS Clinical Trials Group Protocol 076 Study Group. N Engl J Med 1994;331:1173-80.

4. Panel on Treatment of HIV-Infected Pregnant Women and Prevention of Perinatal Transmission. Recommendations for use of antiretroviral drugs in pregnant HIV-1-infected women for maternal health and interventions to reduce perinatal HIV transmission in the United States. March 2014. < http://aidsinfo. nih.gov/contentfiles/lvguidelines/perinatalgl.pdf $>$ (Accessed February 15, 2015).

5. Money D, Tulloch K, Boucoiran I, et al. Guidelines for the care of pregnant women living with HIV and interventions to reduce perinatal transmission: Executive summary. J Obstet Gynaecol Can 2014;36:721-51.

6. Read JS, Cohen RA, Hance LF, et al. Missed opportunities for prevention of mother-to-child transmission of HIV-1 in the NISDI Perinatal and LILAC cohorts. Int J Gynaecol Obstet 2012;119:70-5.

7. Floridia M, Ravizza M, Tamburrini E, et al. Diagnosis of HIV infection in pregnancy: Data from a national cohort of pregnant women with HIV in Italy. Epidemiol Infect 2006;134:1120-7.

8. Nobrega I, Travassos AG, Haguihara T, Amorim F, Brites C. Use of raltegravir in late-presenting, HIV-infected pregnant women. AIDS Res Hum Retroviruses 2013;29:1451-4.

9. Bitnun A, Lee T, Singer J, et al. Missed opportunities for the prevention of vertical HIV transmission (VT): Evidence from the Canadian Perinatal HIV Surveillance Program (CPHSP). Can J Infect Dis Med Microbiol 2013;24(Suppl A):P084

10. ACOG Committee Opinion No. 418: Prenatal and perinatal human immunodeficiency virus testing: Expanded recommendations. Obstet Gynecol 2008;112:739-42.

11. Rokas KE, Bookstaver PB, Shamroe CL, et al. Role of raltegravir in HIV-1 management. Ann Pharmacother 2012;46:578-89.

12. Grinsztejn B, Nguyen BY, Katlama C, et al. Safety and efficacy of the HIV-1 integrase inhibitor raltegravir (MK-0518) in treatmentexperienced patients with multidrug-resistant virus: A phase II randomised controlled trial. Lancet 2007;369:1261-9. follow the VL and allow for a safe vaginal delivery. Indeed, in previously published cases of pregnant women treated with RAL $(8,15,16,18,20$ $22,24-26)$ as well as in the three cases presented here, VL were retrospectively found to be $<1000$ copies/mL after Caesarean section was performed to decrease the risk of perinatal transmission. Availability of rapid HIV quantitative polymerase chain reaction would assist the clinician to better decide whether Caesarean delivery is indicated, according to their national guidelines $(4,5)$.

\section{CONCLUSIONS}

Our findings support the consideration of the use of RAL to reduce the risk of perinatal transmission in late-presenting HIV-infected pregnant women and in women with VL rebound near term. However, longterm data are needed to assess the impact of RAL use for short-term therapy in the obstetrical setting on the resistance profile. Indeed, there is a legitimate concern about the effectiveness of future RALbased regimens. Moreover, current Canadian (5) and United States perinatal guidelines (4) are permissive but do not advocate for RAL use in this setting due to the lack of established data. The results of two ongoing clinical trials (NCT01854762 and NCT01618305) will help to assess advantages of RAL compared with other antiretrovirals in pregnancy. Further research needs to be performed to understand the role of RAL in women with HIV acquisition in pregnancy, who are at even higher risk for perinatal transmission.

ACKNOWLEDGEMENTS: The authors thank Silvie Valois, research nurse at the Centre Maternel Infantile sur le SIDA, for her help in collecting the data. IB was funded by a scholarship of the Sainte-Justine foundation.

13. Lennox JL, DeJesus E, Lazzarin A, et al. Safety and efficacy of raltegravir-based versus efavirenz-based combination therapy in treatment-naive patients with HIV-1 infection: A multicentre, double-blind randomised controlled trial. Lancet 2009;374:796-806

14. Markowitz M, Morales-Ramirez JO, Nguyen BY, et al. Antiretroviral activity, pharmacokinetics, and tolerability of MK-0518, a novel inhibitor of HIV-1 integrase, dosed as monotherapy for 10 days in treatment-naive HIV-1-infected individuals. J Acquir Immune Defic Syndr 2006;43:509-15.

15. Pinnetti C, Baroncelli S, Villani P, et al. Rapid HIV-RNA decline following addition of raltegravir and tenofovir to ongoing highly active antiretroviral therapy in a woman presenting with high-level HIV viraemia at week 38 of pregnancy. J Antimicrob Chemother 2010;65:2050-2.

16. McKeown DA, Rosenvinge M, Donaghy S, et al. High neonatal concentrations of raltegravir following transplacental transfer in HIV-1 positive pregnant women. AIDS 2010;24:2416-8.

17. Jaworsky D, Thompson C, Yudin MH, et al. Use of newer antiretroviral agents, darunavir and etravirine with or without raltegravir, in pregnancy: A report of two cases. Antivir Ther 2010;15:677-80.

18. Taylor N, Touzeau V, Geit M, et al. Raltegravir in pregnancy: A case series presentation. Int J STD AIDS 2011;22:358-60.

19. Lopez-Varela E, Rojo-Conejo P, Blazquez-Gamero D, Gonzalez-Granado L. [Undetectable viral load after the addition of raltegravir in a 36 week pregnant adolescent with high-level HIV viraemia]. An Pediatr (Barc) 2012;76:296-7.

20. Hegazi A, McKeown D, Doerholt K, Donaghy S, Sadiq ST, Hay P. Raltegravir in the prevention of mother-to-child transmission of HIV-1: Effective transplacental transfer and delayed plasma clearance observed in preterm neonates. AIDS 2012;26:2421-3.

21. Westling K, Pettersson K, Kaldma A, Naver L. Rapid decline in HIV viral load when introducing raltegravir-containing antiretroviral treatment late in pregnancy. AIDS Patient Care STDS 2012;26:714-7.

22. Croci L, Trezzi M, Allegri MP, et al. Pharmacokinetic and safety of raltegravir in pregnancy. Eur J Clin Pharmacol 2012;68:1231-2.

23. Renet S, Closon A, Brochet MS, Bussieres JF, Boucher M. Increase in transaminase levels following the use of raltegravir in a woman with a high HIV viral load at 35 weeks of pregnancy. J Obstet Gynaecol Can 2013;35:68-72. 
24. Hegazi A, Hay P. HIV seroconversion in the third trimester of pregnancy: Using raltegravir to prevent mother-to-child transmission. Int J STD AIDS 2013.

25. Cha A, Shaikh R, Williams S, Berkowitz LL. Rapid reduction in HIV viral load in late pregnancy with raltegravir: A case report. J Int Assoc Provid AIDS Care 2013:12:312-4.

26. De Hoffer L, Di Biagio A, Bruzzone B, et al. Use of raltegravir in a late presenter HIV-1 woman in advanced gestational age: Case report and literature review. J Chemother 2013;25:181-3.

27. World Health Organization. ARV drugs adverse events, case definition, toxicity grading and laboratory diagnosis. Geneva (Switzerland) 2008. <http://hivforumannals.org/index.php/ annals/article/download/12/9> (Accessed May 28, 2015).

28. Clarke DF, Acosta EP, Rizk M, et al. Raltegravir Pharmacokinetics and Safety in Neonates (IMPAACT P1097). Atlanta: Conference on Retroviruses and Opportunistic Infections, March 2013.

29. Watts DH, Stek A, Best BM, et al. Raltegravir pharmacokinetics during pregnancy. J Acquir Immune Defic Syndr 2014;67:375-81.

30. Else LJ, Taylor S, Back DJ, Khoo SH. Pharmacokinetics of antiretroviral drugs in anatomical sanctuary sites: The fetal compartment (placenta and amniotic fluid). Antivir Ther 2011;16:1139-47
31. Merck Canada Inc. Product monograph. ISENTRESS®. Kirkland, Quebec, 2013. <www.merck.ca/assets/en/pdf/products/ ISENTRESS-PM_E.pdf> (Accessed May 28, 2015).

32. Brainard DM, Wenning LA, Stone JA, Wagner JA, Iwamoto M. Clinical pharmacology profile of raltegravir, an HIV-1 integrase strand transfer inhibitor. J Clin Pharmacol 2011;51:1376-402.

33. Patel D, Cortina-Borja M, Thorne C, Newell ML. Time to undetectable viral load after highly active antiretroviral therapy initiation among HIV-infected pregnant women. Clin Infect Dis 2007;44:1647-56.

34. Administration. UFaD. Highlights of Prescribing Information. Isentress (relategravir) Tablets 2009. <www.accessdata.fda.gov/ drugsatfda_docs/label/2009/022145s004lbl.pdf> (Accessed May 28, 2015).

35. Read JS, Tuomala R, Kpamegan E, et al. Mode of delivery and postpartum morbidity among HIV-infected women: The women and infants transmission study. J Acquir Immune Defic Syndr 2001;26:236-45.

36. Louis J, Buhari MA, Allen D, Gonik B, Jones TB. Postpartum morbidity associated with advanced HIV disease. Infect Dis Obstet Gynecol 2006;2006:79512. 


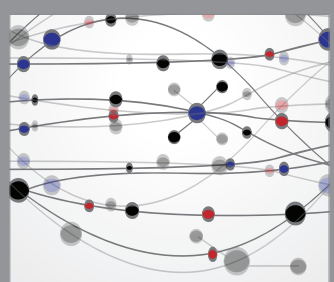

The Scientific World Journal
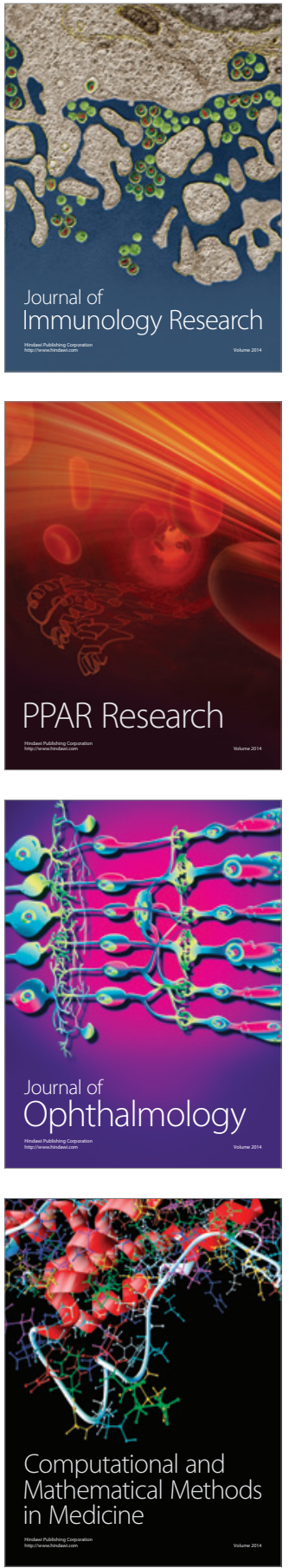

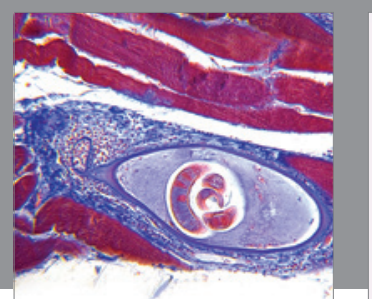

Gastroenterology Research and Practice

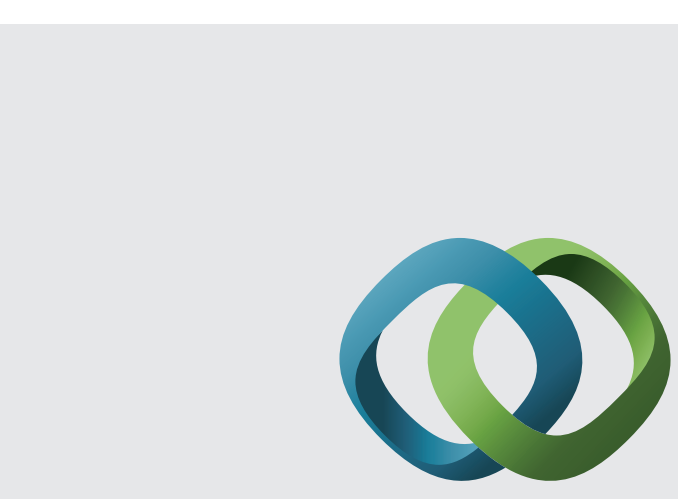

\section{Hindawi}

Submit your manuscripts at

http://www.hindawi.com
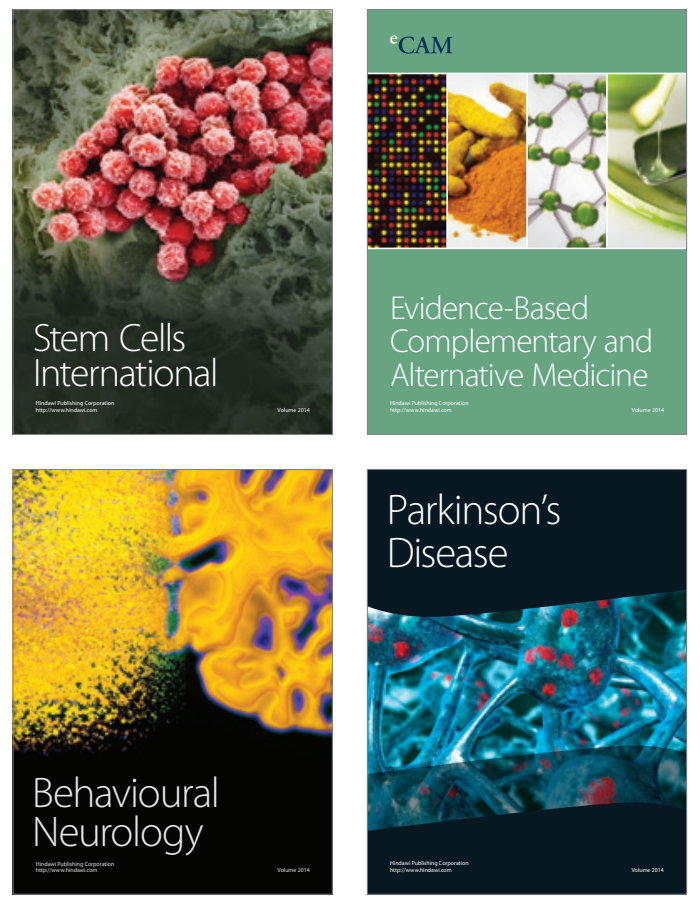
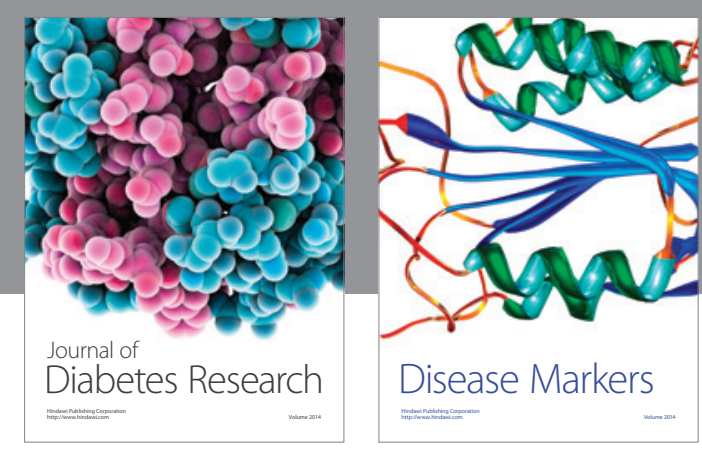

Disease Markers
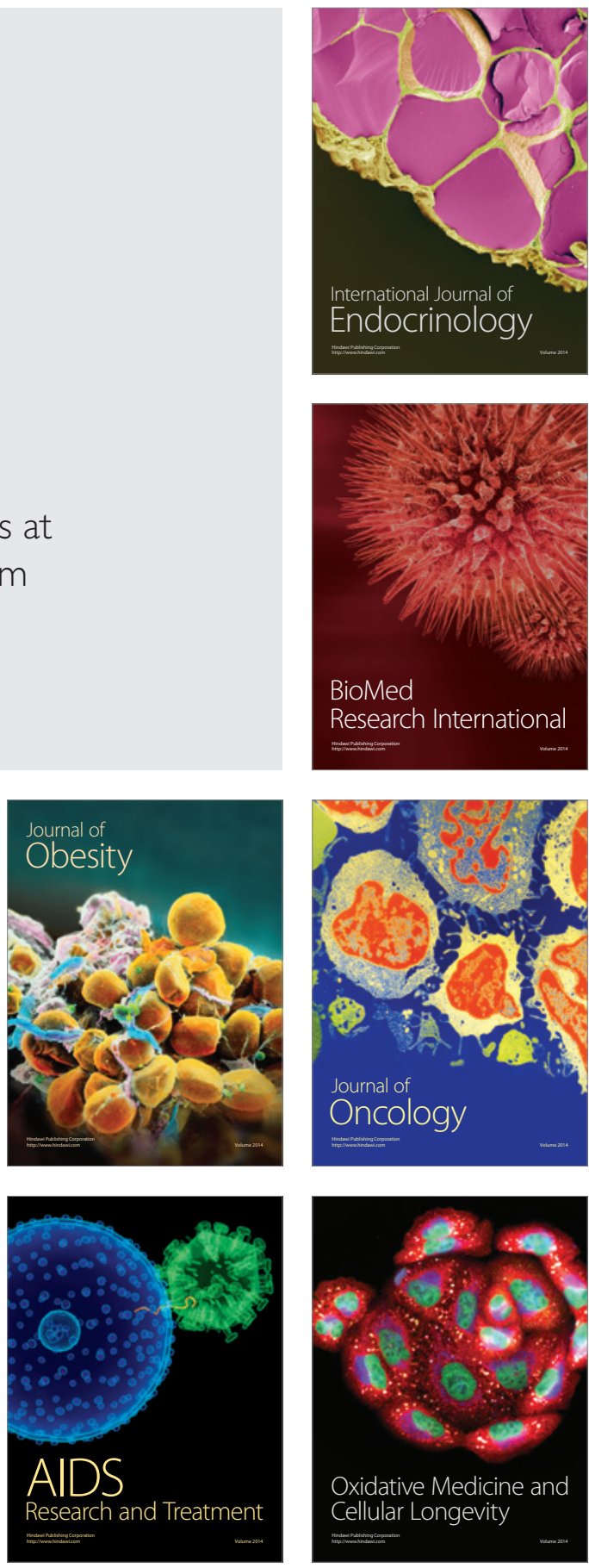